\title{
Limit of detection of Toxocara canis larvae in experimentally contaminated bovine milk
}

\section{Limite de detecção de larvas de Toxocara canis em leite bovino experimentalmente contaminado}

\author{
Edlayne Larissa Gretter Machado Pereira'; Vamilton Alvares Santarém²*; \\ Aline da Silveira Batista ${ }^{3}$; Yslla Fernanda Fitz Balo Merigueti'; \\ Lundia Luara Cavalcante Bin $^{4}$
}

\begin{abstract}
This study aimed to evaluate the limit of detection of Toxocara canis larvae in experimentally contaminated commercial bovine milk samples, based on a centrifuge-sedimentation technique. Firstly, bovine milk (whole and skim) samples were contaminated with $50 \mathrm{~T}$. canis larvae in order to evaluate the interference of milk fat with the recovery of the larvae. Next, the effects of $10 \%$ formalin $(100$ $\mu \mathrm{L})$, ether $(100 \mu \mathrm{L})$, and a combination of both solutions on the recovery of the larvae was examined. Thereafter, the limit of detection of the larvae was determined using the solution (from step 2) considered optimal for degreasing the milk sample. Samples were contaminated with aliquots of 1, 5, 10,25 , and 50 larvae. For each milk sample $(1.0 \mathrm{~mL}), 15$ repetitions were analysed. The recovery of the larvae from the skim milk samples was higher $(p=0.0031)$ than that from the whole milk samples. No significant difference $(p=0.5681)$ was observed with regard to the percentage of recovered larvae when comparing the degreasing solutions. Nevertheless, the formalin-ether combination was more efficient for recovering the larvae (73.1\%) than ether $(71.9 \%)$, formalin $(67.6 \%)$, and pure whole milk $(70.0 \%)$. Concerning the limit of detection (using formalin-ether), all the samples contaminated with 5, 10, 25, and 50 larvae tested positive (minimum: 62.7\%). Of the samples contaminated with a single larva, $66.7 \%$ tested positive. These results suggest that the centrifugation-sedimentation technique may be useful for recovering larvae of Toxocara spp. in naturally or experimentally contaminated milk samples obtained from a wide range of animal species.
\end{abstract}

Key words: Toxocariasis, recovery of larvae, diagnosis

\section{Resumo}

O objetivo do estudo foi avaliar o limite de detecção de larvas de Toxocara canis em leite bovino comercial contaminado experimentalmente, a partir de uma técnica de centrifugo-sedimentação. Primeiramente, amostras de leite bovino comercial (integral e desnatado) foram contaminadas com 50 larvas de T. canis, para avaliação da interferência da gordura sobre a recuperação das larvas. Em uma segunda etapa, foi avaliada a ação de formalina $10 \%(100 \mu \mathrm{L})$, éter $(100 \mu \mathrm{L})$ e combinação das soluções. A terceira etapa consistiu da verificação do limite de detecção de larvas, com uso da melhor solução desengordurante (etapa 2), em amostras de leite $(1,0 \mathrm{~mL})$ contendo $1 ; 5 ; 10 ; 25$ e 50 larvas. Para cada

\footnotetext{
${ }^{1}$ Discentes do Mestrado, Programa de Pós-Graduação em Ciência Animal, Universidade do Oeste Paulista, UNOESTE, Presidente Prudente, São Paulo, Brasil. E-mail: edlaynelarissa@gmail.com; yslla merigueti@hotmail.com

${ }^{2}$ Prof. Programa de Pós-Graduação em Ciência Animal, UNOESTE, Presidente Prudente, SP, Brasil. E-mail: vamilton@unoeste.br

${ }^{3}$ Médica Veterinária Autônoma, Presidente Prudente, SP, Brasil. E-mail: li_sbatista@hotmail.com

${ }^{4}$ Médica Veterinária Autônoma, Mirante do Paranapanema, SP, Brasil. E-mail: lundia.bin@hotmail.com

* Author for correspondence
} 
análise de detecção do leite $(1,0 \mathrm{~mL})$, foram realizadas 15 repetições. Foi observado que o percentual de recuperação de larvas no leite desnatado foi significativamente maior $(\mathrm{p}=0,0031)$ que o observado no leite integral. Na comparação das soluções, não houve diferença significativa $(p=0,5681)$ no percentual de larvas recuperadas. Entretanto, houve uma maior recuperação quando do emprego da combinação de formol-éter $(73,1 \%)$ em relação ao éter $(71,9 \%)$, ao formol $(67,6 \%)$ e ao leite integral puro $(70,0 \%)$. Em relação ao limite de detecção, com uso de formalina-éter, todas as alíquotas apresentaram resultado positivo (mínimo de 62,7\% de larvas recuperadas), para as amostras com 5, 10, 25 e 50 larvas. Nas amostras contaminadas com uma larva, $66,7 \%$ das alíquotas foram positivas. A técnica apresentada poderá servir para recuperação de larvas de Toxocara spp. em amostras de leite de várias espécies animais, contaminados naturalmente ou experimentalmente.

Palavras-chave: Toxocaríase, recuperação de larvas, diagnóstico

\section{Introduction}

Toxocariasis is one of the most prevalent helminth zoonoses (RUBINSKY-ELEFANT et al., 2010). It is primarily caused by the nematode Toxocara canis, whose definitive host is the dog (DESPOMMIER, 2003; SANTARÉM et al., 2011).

Transmission of T. canis in dogs is predominantly transplacental (DESPOMMIER, 2003), but it can also spread via transmammary route (SANTARÉM et al., 2014), through ingestion of embryonated eggs present in the environment or ingestion of paratenic hosts (MAGNAVAL et al., 2001).

Currently, T. canis is known to be transmitted to humans through accidental ingestion of soil containing embryonated eggs or raw or undercooked meat of paratenic hosts (MAGNAVAL et al., 2001; DESPOMMIER, 2003); however, a case of congenital ocular toxocariasis in a premature newborn has also been reported (MAFFRAND et al., 2006).

In an indexed search of the literature, no references were found to the transfer of larvae through breast milk in humans. However, studies using experimental models have confirmed the transmission of Toxocara larvae via transmammary routes, by examining tissue samples of neonatal mice (REITEROVÁ et al., 2003; JIN et al., 2008; SOUZA AGUIAR et al., 2014), mice at 50 days of age (TELMO et al., 2015), and directly through rabbit milk (SANTARÉM et al., 2014). Nonetheless, the limit of detection of the technique presented by these authors in detecting larvae has not been evaluated.

Therefore, this study aimed to assess the limit of detection of $T$. canis larvae using the centrifugesedimentation technique, adopting cow's milk as a model.

\section{Material and Methods}

\section{Collection and incubation of Toxocara canis eggs}

Eggs of adult $T$. canis females were collected; these nematodes were released spontaneously in the faeces of puppies of naturally infected dogs that were housed in the Unoeste kennel (Universidade do Oeste Paulista, Presidente Prudente, São Paulo, Brazil).

The adult females (fifth stage larvae $\left[\mathrm{L}_{5}\right]$ ) of the parasite were placed in plastic containers and sent to the Laboratory of Preventive Veterinary Medicine II (Veterinary Parasitology) of the Veterinary Hospital of the same institution.

$\mathrm{L}_{5}$ larvae were initially exposed to $1 \%$ sodium hypochlorite solution for $5 \mathrm{~min}$ and washed with $0.9 \%$ saline solution to remove any debris. Immediately afterwards, the anterior third of the uterus was dissected to extract the eggs (FAN; SU, 2004).

For embryonation, the eggs were transferred to a $50-\mathrm{mL}$ Falco tube containing $0.1 \mathrm{~N}$ sulphuric acid 
solution (diluted 1:10), where they were incubated at $27^{\circ} \mathrm{C} \pm 30^{\circ} \mathrm{C}$ for at least 28 days.

Embryogenesis was monitored and larvae within the eggs were evaluated periodically using an optical microscope (Nikon E200) (10×).

\section{Collection of Toxocara canis larvae}

The Baermann technique (HOFFMANN, 1987) with minor modifications was used to obtain T. canis larvae. Aliquots of the embryonated eggs (approximately $1.0 \mathrm{~mL}$ ) were transferred to conical tubes and subjected to centrifugation $(1428 \times g, 5 \mathrm{~min})$ to remove remnant sulphuric acid. After removal of the supernatant containing the acid, the tube contents were washed with 5.0 $\mathrm{mL}$ of distilled water and centrifuged twice more (1428 $\times g, 5 \mathrm{~min})$. Next, the sediment containing the eggs was transferred to a Petri dish containing $5.0 \mathrm{~mL}$ of $5 \%$ sodium hypochlorite solution for 3 min to weaken the membrane of the eggs and cause the larvae to hatch. Following this, the material was centrifuged again to remove the hypochlorite and washed twice in distilled water (1428 x g, 5 $\min )$.

The tubes were heated in a bain-marie $\left(37^{\circ} \mathrm{C}\right.$, 10 min. FANEM - Model 100. São Paulo, Brazil) and glass beads were placed in the tubes to facilitate the egg breaking process. The material was homogenized vigorously using a tube shaker (2 min. FANEM - Model 251. São Paulo, Brazil) and then slowly using a blood homogenizer (15 min, 30 rpm. FANEM - Model 251. São Paulo, Brazil). Following this, the sample was placed into a bainmarie $\left(37^{\circ} \mathrm{C}, 10 \mathrm{~min}\right)$.

The material was placed on prepared gauze in a Baermann funnel, where it was allowed to stand overnight $\left(27^{\circ} \mathrm{C} \pm 30^{\circ} \mathrm{C}\right)$. Thereafter, the recovered larvae were stored in refrigerated conditions $\left(7^{\circ} \mathrm{C}\right)$ until the time of separation and counting for the formation of aliquots.

\section{Formation of aliquots}

For preparation of the aliquots containing the parasite eggs, $10 \mu \mathrm{L}$ of the material resulting from the Baermann technique described above was placed on a histological slide. The larvae were counted microscopically $(4 \times)$ and, with the aid of a pipet $(20 \mu \mathrm{L})$, sucked up individually and transferred to Eppendorf microcentrifuge tubes containing $200 \mu \mathrm{L}$ of distilled water. The aliquots were composed of 1 , $5,10,25$, and 50 larvae.

\section{Contamination and recuperation of Toxocara canis} larvae from milk samples

"Long life" ultra-heat treated (UHT) bovine milk was used in this study: skim (Molico ${ }^{\circledR}$, Nestlé) in addition to whole milk (Ninho ${ }^{\circledR}$, Nestlé), with fat contents of $0.4 \%$ and $3.5 \%$, respectively, according to the composition specified by the manufacturer.

T. canis larvae were recovered from the milk of experimentally infected rabbits by using the formalin-ether technique described by Ritchie (1948) and used by Santarém et al. (2014), with minor modifications.

In the present study, the volume of milk samples was standardized to $1.0 \mathrm{~mL}$ for each aliquot tested. The milk sample was transferred to conical centrifuge tubes to which the aliquots containing the larvae were added.

For recovery of the larvae, $100 \mu \mathrm{L}$ of $10 \%$ formalin solution was added to the milk and the resulting mixture was left to rest for $2 \mathrm{~min}$, allowing it to gently homogenize. Next, $100 \mu \mathrm{L}$ of $70 \%$ ethylic ether was added, and left to rest ( $2 \mathrm{~min}$ ) and homogenize. After this process, the samples were centrifuged $(1428 \times g, 5 \mathrm{~min})$. To count the larvae, six $50.0 \mu \mathrm{L}$ aliquots were taken from the sediment and analysed between a slide and cover slip $(22 \times 22 \mathrm{~mm})$ under an optical microscope $(10 \times)$. 
A second reading of the six aliquots was performed after mild homogenization and centrifugation $(1428 \times g, 5 \mathrm{~min})$.

\section{Evaluation steps}

Initially, aliquots of skim and whole milk contaminated with 50 larvae were compared to evaluate the effect of milk fat content on the recovery of larvae

The second step was to evaluate whether the solutions interfered in the recovery of larvae. The numbers of larvae recovered in samples containing 50 larvae were compared (15 aliquots) from milk samples treated with $10 \%$ formalin, $70 \%$ ethylic ether, formalin-ether and no milk treatment.

The final step was to study the limit of detection of larvae in the milk samples. From the technique that presented the best results in the previous steps (1 and 2), the recovery quantity was evaluated in decreasing order for aliquots containing 50, 25, 10 , 5 , and 1 larva per $\mathrm{mL}$ of milk.

A sample of $1.0 \mathrm{~mL}$ of UHT whole milk was used as a control, and subjected to the same procedures adopted for those which were contaminated. For each testing repetition with different aliquots of larvae, a control sample was assessed.

\section{Statistical analysis}

For each detection analysis, 15 aliquots were evaluated in a preliminary study. Of these, the aliquots containing 10,25 , and 50 larvae that showed recovery of at least $50 \%$ of the larvae were considered suitable for further analysis.

Normality assumption was assessed using the Shapiro-Wilk test. In order to compare the percentage recovery of larvae in skim and whole milk samples, unpaired $t$ test was used. One-way analysis of variance was used to comparatively analyse the percentage of larvae recovered using $10 \%$ formalin, $70 \%$ diethyl ether, formalin-ether combination, and pure whole milk. The significance level was set at $5 \%(p<0.05)$ for all analyses.

\section{Results}

According to the results obtained from the first stage (Table 1), the percentage recovery of larvae in skim milk was significantly higher $(81.2 \%$; $\mathrm{p}=$ $0.0031)$ than that observed in whole milk $(70.0 \%)$. When different solutions used in the technique adopted in this study were compared, no significant difference was found in the percentage of recovered larvae $(\mathrm{p}=0.5681)$, including the pure milk samples (Table 2). However, using the combination of formalin-ether resulted in greater recovery $(73.1 \%)$ than using ether $(71.9 \%)$, pure whole milk $(70.0 \%)$, and formalin $(67.6 \%)$ alone. Thus, to assess the limit of detection of the larvae, the formalin-ether solution was employed.

This technique using the formalin-ether combination enabled the recovery of at least one larva in all tests performed using aliquots containing between 50 and 5 larvae. Approximately $67 \%$ of the samples with 1 larva yielded positive results; the remaining $33 \%$ were false-negatives.

Table 1. Percentage (\%) and average number of Toxocara canis larvae recovered from skim and whole milk samples $(1.0 \mathrm{~mL})$ contaminated with 50 larvae (15 repetitions) using a centrifuge-sedimentation technique with formalin-ether.

\begin{tabular}{lccc}
\hline \multicolumn{4}{c}{ Recovery of larvae } \\
\hline \multicolumn{1}{c}{ Type of milk } & Average (\%) \pm SD (variation) & Average number \pm SD (variation) & p-value \\
\hline Skim & $81.2 \pm 8.7(70-96)$ & $40.6 \pm 4.4(35-48)$ & 0.031 \\
Whole & $70.0 \pm 10.2(50-84)$ & $35.0 \pm 5.1(25-42)$ & 0.0031 \\
\hline
\end{tabular}

$\mathrm{SD}=$ standard deviation 
Table 2. Percentage (\%) and average number of Toxocara canis larvae recovered from samples of whole milk (1.0 $\mathrm{mL}$ ) infected with 50 larvae (15 repetitions). A centrifuge-sedimentation technique was used to compare the effects of $10 \%$ formalin, $70 \%$ ethyl ether, and a combination formalin-ether on larval recovery.

\begin{tabular}{lccc}
\hline \multicolumn{4}{c}{ Recovery of larvae } \\
\hline \multicolumn{1}{c}{ Solution } & Average percentage (variation) & Average number (variation) & p-value \\
\hline Formalin & $67.6(52-80)$ & $33.8(26-40)$ & 0.5681 \\
Pure milk & $70.0(50-84)$ & $35.0(25-42)$ & \\
Ether & $71.9(50-88)$ & $35.9(25-44)$ & \\
Formalin-ether & $73.1(52-92)$ & $36.5(26-46)$ & \\
\hline
\end{tabular}

The larvae were recovered in all tests, except for the samples contaminated with 1 larva, wherein 10 of the 15 samples $(66.7 \%)$ tested positive (Table 3 ). On average, a minimum of $62.7 \%$ of larvae were recovered in all tests.

Table 3. Percentage (\%) and average number of Toxocara canis larvae recovered from whole milk samples (1.0 mL) contaminated with $50,25,10,5$, and 1 larva (15 repetitions) using a centrifuge-sedimentation technique to assess the limit of detection of larvae.

\begin{tabular}{cccc}
\hline $\begin{array}{c}\text { Aliquots } \\
\text { (larvae) }\end{array}$ & $\begin{array}{c}\text { Aliquots positive/repetitions } \\
(\%)\end{array}$ & $\begin{array}{c}\text { Average percentage of larvae } \\
\text { recovered (variation) }\end{array}$ & $\begin{array}{c}\text { Average number of larvae } \\
\text { recovered (variation) }\end{array}$ \\
\hline $\mathbf{5 0}$ & $15 / 15(100)$ & $73.0(52-92)$ & $36.5(26-46)$ \\
$\mathbf{2 5}$ & $15 / 15(100)$ & $65.0(48-84)$ & $16.2(12-21)$ \\
$\mathbf{1 0}$ & $15 / 15(100)$ & $63.3(50-90)$ & $6.33(5-9)$ \\
$\mathbf{5}$ & $15 / 15(100)$ & $62.7(20-100)$ & $3.1(1-5)$ \\
$\mathbf{1}$ & $10 / 15(66.7)$ & $66.7(0-100)$ & $0.7(0-1)$ \\
\hline
\end{tabular}

No alterations were observed in the integrity of the larvae. However, the majority became motionless when subjected to the solutions used in the centrifugal-sedimentation technique. In contrast, all larvae recovered from the pure whole milk samples maintained their motility. Furthermore, the larvae exposed to the action of formalin were predominantly spiral shaped, whereas those subjected only to ether treatment were elongated. When both solutions were used in combination, approximately $50 \%$ of the larvae were found to be spiral-shaped and half were elongated. No larvae were found in the control samples.

\section{Discussion and Conclusions}

In the present study, the recovery of larvae from skim milk samples was found to be significantly greater than that from the whole milk samples. This difference could be attributed to the higher fat content of whole milk, which probably interfered with the readings of the observation of the larvae. It is likely that the larvae were retained in the fat, thereby reducing the rate of recovery, as suggested by Santarém et al. (2014).

A centrifugal-sedimentation technique was used for larval recovery. The effects of the different solutions (formalin-ether, formalin, and ether) used individually and in combination were compared. 
Although there was no significant difference in the recovery, the formalin-ether combination presented the best results. The effect of ether and formalin probably allowed greater lipolysis; this postulation was confirmed by the analysis of aliquots, when the presence of fat droplets resulted in the release of larvae. The recovery of larvae from pure whole milk samples demonstrated that centrifugation alone enabled sedimentation of the larvae.

In view of the results obtained for the formalinether, this solution was adopted to evaluate the limit of detection of the centrifuge-sedimentation technique.

In the present study, the formalin-ether solution was adopted because of the observed greater recovery of larvae. The technique enabled considerable recovery of larvae even in samples contaminated with only one larva. The above-described technique can be used both for quantitative studies in animals that have been experimentally infected with a predefined infective dose, and in a qualitative way, with naturally infected animals, since the quantity of these parasitic structures is unknown in these circumstances.

It was observed that the integrity of the larvae was maintained upon exposure to solutions used to degrease milk. However, spiral-shaped larvae were identified in milk subjected to formalinether treatment, which was consistent with the findings of Santarém et al. (2014), who studied experimentally infected rabbits' milk. Although the presence of spiral larvae may be a limitation for morphometric characterization when employing formalin-ether, it was possible to recover a sufficient number of larvae to enable morphometry. Thus, it may be possible to classify the genus of the recovered ascarid from naturally infected animal's milk. Nonetheless, further studies are needed to investigate solutions that enable the breakdown of fat molecules in milk and do not interfere in the morphometry of the larvae.
The centrifuge-sedimentation technique presented in this study is an easy, non-time consuming method that allows the recovery of larvae in samples that contain a small number of these structures. Furthermore, the equipment and reagents required are inexpensive.

The technique presented in this study could be successfully used for the recovery of larvae from milk in conjunction with techniques for molecular characterization of parasites. PCR has served to enable molecular characterization of faecal samples of dogs and cats as well as soil containing eggs of Toxocara spp. (FOGT-WYRWAS et al., 2007; FAHRION et al., 2011; DURANT et al., 2012; KHADEMVATAN et al., 2013, 2014). PCR technique was applied in an experimental study to evaluate bronchoalveolar lavage (PINELLI et al., 2013) and also to confirm the diagnosis of human toxocariasis from CSF samples to isolate the cause of neurological syndrome (CALDERA et al., 2012). Molecular characterization of a Toxocara larva, identified as T. canis, present in the left eye of a man with a vision loss complaint and eye pain has also been possible using this technique (VAN DE et al., 2013).

Inconclusion, this technique could be successfully applied to the detection of Toxocara larvae present in low numbers in milk samples, with a limit of detection of a minimum of one larva. Furthermore, it may serve to evaluate the transmammary route of transmission of these nematodes in various animal species, whether naturally or experimentally infected.

\section{References}

CALDERA, F.; BURLONE, M. E.; GENCHI, C.; PIRISI, M.; BARTOLI, E. Toxocara encephalitis presenting with autonomous nervous system involvement. Infection, Berlin, v. 41, n. 3, p. 691-694, 2012.

DESPOMMIER, D. Toxocariasis: clinical aspects, epidemiology, medical ecology, and molecular aspects. Clinical Microbiology Review, Washington, v. 16, n. 2, p. 265-272, 2003. 
DURANT, J-F.; IRENGE, L. M.; FOGT-WYRWAS, R.; DUMONT, C.; DOUCET, J-P.; MIGNON，B.; LOSSON, B.; GALA, J-L. Duplex quantitative real-time PCR assay for the detection and discrimination of the eggs of Toxocara canis and Toxocara cati (Nematoda, Ascaridoidea) in soil and fecal samples. Parasites \&Vectors, London, v. 5, p. e288, dez. 2012.

FAHRION, A. S.; SCHNYDER, M.; WICHERT, B.; DEPLAZES, P. Toxocara eggs shed by dogs and cats and their molecular and morphometric species-specific identification: Is the finding of $T$. cati eggs shed by dogs of epidemiological relevance? Veterinary Parasitology, Amsterdam, v. 177, n. 1-2, p. 186-189, 2011.

FAN, C. K.; SU, K. E. Cross-reactions with Ascaris suum antigens of sera from mice infected with $A$. suum, Toxocara canis, and Angiostrongylus cantonensis. Parasitology International, Amsterdam, v. 53, n. 3, p. 263-271, 2004.

FOGT-WYRWAS, R.; JAROSZ, W.; MIZGAJSKAWIKTOR, H. Utilizing a polymerase chain reaction method for the detection of Toxocara canis and T. cati eggs in soil. Journal of Helminthology, London, v. 81, n. 1, p. 75-78, 2007.

HOFFMANN, R. P. Diagnóstico de parasitismo veterinário. Porto Alegre: Sulina, 1987. 155 p.

JIN, Z.; AKAO, N.; OHTA, N. Prolactin evokes lactational transmission of larvae in mice infected with Toxocara canis. Parasitology International, Amsterdam, v. 57, n. 4, p. 495-498, 2008.

KHADEMVATAN, S.; ABDIZADEH, R.; TAVALLA, M. Molecular characterization of Toxocara spp. from soil of public areas in Ahvaz southwestern Iran. Acta Tropica, Basel, v. 135, p. 50-54, jul. 2014.

KHADEMVATAN, S.; RAHIM, F.; TAVALLA, M.; ABDIZADEH, R.; HASHEMITABAR, M. PCR-based molecular characterization of Toxocara spp. using feces of stray cats: A study from Southwest Iran. Plos One, San Francisco, v. 8, n. 6, p. e65293, 2013.

MAFFRAND, R.; AVILA-VÁZQUEZ, M.; PRINCICH, D.; ALASIA, P. Toxocariasis ocular congénita en um recien nacido prematuro. Anais de Pediatria, Barcelona, v. 64 , n. 6, p. 595-604, 2006.

MAGNAVAL, J. F.; GLICKMAN, L. T.; DORCHIES, P.; MORASSIN, B. Highlights of human toxocariasis. Korean Journal of Parasitology, Seoul, v. 39, n. 1, p. 1-11, 2001.
PINELLI, E.; ROELFSEMA, J. H.; BRANDES, S.; KORTBEEK, T. Detection and identification of Toxocara canis DNA in bronchoalveolar lavage of infected mice using a novel real-time PCR. Veterinary Parasitology, Amsterdam, v. 193, n. 4, p. 337-341, 2013.

REITEROVÁ, K.; TOMASOVICOVÁ, O.; DUBINSKÝ, $P$. Influence of maternal infection on offspring immune response in murine larval toxocariasis. Parasite Immunology, London, v. 25, n. 7, p. 361-368, 2003.

RITCHIE, L. S. An ether sedimentation technique for routine stool examination. Bulletin of the United States Army Medical Department, Fort Sam Houston, v. 8, n. 4, p. 326, 1948.

RUBINSKY-ELEFANT, G.; HIRATA, C. E.; YAMAMOTO, J. H.; FERREIRA, M. U. Human toxocariasis: diagnosis, worldwide seroprevalences and clinical expression of the systemic and ocular forms. Annals of Tropical Medicine and Parasitology, London, v. 104, n. 1, p. 3-23, 2010.

SANTARÉM， V. A.; RUBINSKY-ELEFANT, G.; FERREIRA, M. U. Soil-transmitted helminthic zoonoses in humans and associated risk factors. In: PASCUCCI, S. (Ed.). Soil contamination. Rijeka: InTech, 2011. p. 43-66. Available: <http://www.intechopen.com/articles/show/ title/soil-transmitted-helminthic-zoonoses-in-humansand-associated-risk-factors $>$. Accessed at: 15 jan. 2015.

SANTARÉM, V. A.; EXPOSTO, C. F. S.; RAMIRES, L. M.; BIN, L. L. C.; RUBINSKY-ELEFANT, G.; LAPOSY, C. B.; NOGUEIRA, R. M. B. Detection of larvae of Toxocara canis in milk: an experimental study in rabbits. Semina: Ciências Agrárias, Londrina, v. 35, n. 1, p. 357-364, 2014.

SOUZA AGUIAR, P. de; FURTADO, R. D.; AVILA, L. F. de; LIMA TELMO, P. de; MARTINS, L. H.; BERNE, M. E.; SILVA, P. E. da; SCAINI, C. J. Transmammary infection in BALB/c mice with chronic toxocariasis. Parasitology International, Amsterdam, v. 64, n. 2, p. 145-147, 2014.

TELMO, P. de L.; AVILA, L. F.; SANTOS, C. A.; AGUIAR, P. de S.; MARTINS, L. H.; BERNE, M. E.; SCAINI, C. J. Elevated trans-mammary transmission of Toxocara canis larvae in $\mathrm{Balb} / \mathrm{c}$ mice. Revista do Instituto de Medicina Tropical de São Paulo, São Paulo, v. 57, n. 1, p. 85-87, 2015.

VAN DE, N.; TRUNG, N. V.; LE DUYET, V.; CHAI, J. Y. Molecular diagnosis of an ocular toxocariasis patient in Vietnam. Korean Journal of Parasitology, Seoul, v. 51, n. 5, p. 563-567, 2013. 
